\title{
РАЗВИТИЕ СТРУКТУРЫ МАКРОКОНЦЕПТА ДЕРЖАВА ОТ МОТИВИРУЮЩИХ ПРИЗНАКОВ ДО ПОНЯТИЙНЫХ
}

\author{
Е. Е. Демидова \\ Институт иностранных языков
}

\section{THE DEVELOPMENT OF THE STRUCTURE OF THE ДЕРЖAВА (POWER) MACROCONCEPT FROM MOTIVATING SIGNS TO CONCEPTUAL ONES}

\author{
E. E. Demidova \\ Institute of the Foreign Languages
}

\begin{abstract}
Аннотация: иель статьи - определение базовых признаков макроконцепта держава. Задачи статьи: 1) посредством анализа основного репрезентанта макроконцепта в этимологических словарях выявить мотивирующие признаки макроконцепта; 2) через изучение основного репрезентанта концепта в толковых словарях двух периодов: а) XVIII-XIX вв. и б) XX-XXI вв. найти понятийные признаки макроконцепта держава. Для это было использовано 11 этимологических словарей русского языка, 7 словарей старославянского, иерковнославянского и русского языков ХVIII-ХІХ вв., 11 словарей современного русского языка. Развитие структуры макрокониепта держава первоначально расширяет количество понятийных признаков, а к современному времени сужает их количество. Мотивируюших признаков у данного макрокониепта 19, в период с X по ХІХ в. у него появляется 23 понятийных признака. В современной русской языковой картине мира их 15. Держава относится к разряду угасающих макроконцептов, у которых понятийные признаки меньше по количеству мотивирующих. Понятийные признаки современного макрокониепта держава объединяются в 9 блоков: 1) правление народом ('(верховная/государственная) власть' (мотивир. 'власть'), 'владычество'); 2) взаимоотношения между странами ('влияние (в мировой политике имеждународных делах)', '(самостоятельная) политика'(мотивир. '(самостоятельное/независимое) владение'); 3) земля с границами ('(большая/мощнная страна / независимое/крупное государство') (мотивир. '(самостоятельная) страна/государство'), 'территория (государства) (понят. признак пред. периода 'земля')'); 4) физические способности ('сила'(мотивир. 'сила/крепость'), 'могущество'); 5) возможности и ресурсы ('(большие) достижения (экономические, военные, спортивные и др.)', 'потенциал (экономический/политический)'); 6) опора ('поддержка', 'за что можно держаться/ухватиться (ручка, скоба)'); 7) предмет ('приспособление для держания чего-нибудь, напр. металла при обработке (спеи.)' (в пред. период 'железная полоса (привариваемая временно к выковываемой крупной вещи для удержания и управлению ею на наковальне) / железный прут вилами, употребляемый для сварки железа / подобный стержень для садки серебряных бликов (слитков) в плавильный горн'); 8) знак ('эмблема/ регалия/символ власти монарха: золотой шар с короной или крестом'); 9) физическое свойство ('прочность / твердая связь / надежность в скрепе').
\end{abstract}

Ключевые слова: макрокониепт, мотивирующие признаки, понятийные признаки, концептуальная структура, языковая картина мира, лингвокультурология.

\begin{abstract}
Objectives of the article: 1) identify the motivating signs of the macroconcept by analyzing the main representative of the macroconcept in etymological dictionaries; 2) find the conceptual signs of the depжава (power) macroconcept through the study of the main representative of the concept in the explanatory dictionaries of two periods: a) XVIII-XIX centuries and b) XX-XXI centuries. 11 etymological dictionaries of the Russian language, 7 dictionaries of the Old Slavonic, Church Slavonic and Russian languages of the $18^{\text {th }}-19$ th centuries, 11 dictionaries of
\end{abstract}

(C) Демидова Е. Е., 2021

Контент доступен под лицензией Creative Commons Attribution 4.0 License.

The content is available under Creative Commons Attribution 4.0 License. 
the modern Russian language were taken for the analysis. The development of the structure of the держава (power) macroconcept initially expands the number of conceptual sings, and by modern times it narrows their number. There are 19 motivating signs for this macroconcept; 23 cognitive signs appear in the period from the 18 th to the 19th centuries. There are 15 cognitive signs in the modern Russian language picture of the world. Держава (power) belongs to the category of dying macroconcepts, in which conceptual signs are less in the number of motivating ones. Conceptual signs of the держава (power) modern macroconcept are combined into 9 blocks: 1) rule by the people ('(supreme/state) power' (motivated 'power'), 'dominion'); 2) relationships between countries ('influence (in world politics and international affairs)', '(independent) politics' - motivational ' (independent/independent) ownership'); 3) land with borders ('(large / powerful country / independent / large state') (motivated '(independent) country/state'), 'territory (states) (understandable sign of the previous period 'land')'); 4) physical abilities ('strength' (motivated 'strength/fortress'), 'power'); 5) opportunities and resources ('(great) achievements (economic, military, sports, etc.)', 'potential (economic/political)'); 6) support ('support', 'what you can hold on to / grab onto (handle, bracket)'); 7) object ('a device for holding something, for example metal during processing (special)' (in the previous period 'an iron strip (temporarily welded to a forged large thing to hold and control it on an anvil) / iron rod with a pitchfork, used for welding iron / similar rod for setting silver glare (ingots) into the smelting forge'); 8) sign ('emblem/regalia/symbol of the power of the monarch: a golden ball with a crown or cross'); 9) physical property ('strength / firm bond / reliability in the bond').

Key words: macroconcept, motivating signs, conceptual signs, conceptual structure, language picture of the world, cultural linguistics.

\section{Введение}

Обращение политической лингвистики к макроконцептам власти обусловлено пристальным вниманием к этой сфере жизни общества. Актуальность темы концептуализации власти заключается в анализе такой важной темы, как управление страной и система общественного взаимодействия. Актуальность проблемы обусловлена необходимостью исследования способов вербализации и специфики концептуализации такого фрагмента мира, как власть.

Одним из политических макроконцептов является держава, обойденная вниманием концептологов. Первое обращение к изучению базовых - мотивирующих и понятийных - признаков макроконцепта держава и составляет научную новизну проводимого исследования.

\section{Методы и материал исследования}

Основными методами в статье являются дескриптивный, интерпретативный, метод компонентного анализа словарных дефиниций. Национальный корпус русского языка (www.ruscorpora.ru) стал источником языкового материала. 11 этимологических и историко-этимологических словарей русского языка послужили источником выявления мотивирующих признаков макроконцепта держава. Данные 7 словарей старославянского, церковнославянского и русского языков XVIII-XIX вв., 11 словарей современного русского языка послужили основанием для определения понятийных признаков изучаемого макроконцепта.

\section{Результаты и обсуждение}

В статье поэтапно решаются поставленные задачи. Первый этап - выявление мотивирующих признаков макроконцепта.

\section{1. Мотивирующие признаки макроконцепта держава}

Для определения мотивирующих признаков взято 11 этимологических словарей русского языка. Не во всех этимологических словарях указывается слово держава или глагол держать, от которого это слово производят. В качестве материала исследования выступает словарная статья «держава», где в виде сем и семем перечислены мотивирующие признаки изучаемого макроконцепта.

Слово держа́ва восходит к корню dbrg «дёргать» общеславянского фонда (ст.-слав. дръжава кра́тољ, болг. държа́ва «государство», сербохорв. дрэнава, словен. držâva, чеш. država, польск. dzierżawa «владение, аренда»). Это суффиксальное производное от древнерусского многозначного слова дьржа «сила, крепость; владычество, могущество» путем добавления суффикса -ав- $a$ (как дубрава).

Л. В. Успенский отмечает, что первоначально это слово означало «область, которую властитель держит под своей властью» [1]. Н. В. Горяев в своем словаре слово держава не рассматривает, однако здесь есть словарная статья, посвященная глаголу держать, имеющему значение «владеть, править» [2, с. 89]. При этом старославянский глагол «держ- $a-m u=*$ дерг-гъmu» [там же]. Г. П. Цыганенко отмечает, что старославянское слово дръжава имело значения «сила, власть, могущество» [3, с. 106]. А. Преображенский пишет, что формы древнерусского глагола держати, дьржати образованы от церковнославянских форм дрьжати, дргжстии [4, с. 181].

У слова держава есть еще одно значение: держава - это «золотой шар с короной и крестом, символ власти» [5, с. 111]. Это значение - явный метонимический перенос: «то, что держат в руках»: все русские цари на тожественных церемониях держали в руках 
золотой шар и изображались на официальных полотнах с этим символом власти - предметом, называвшимся держава. Позднее держава стала «синонимом слов государство, самостоятельная страна» [1].

Образование слова произошло с помощью суффикса -j- от одной основы, что и слово дерзкий: zј > ж. Как указывается в словаре Н. М. Шанского, существительное держа со значением «сила, владычество» до сих пор встречается в диалектах [6].
П. Я. Черных показывает развитие значений слова держава: «основа», «основание» («то, что поддерживает, помогает держать или держаться») > «сила, могущество». Позже с XII-XIII вв. появились значения «управление», «государство» [7].

М. Фасмер предлагает обратить внимание еще на одно значение у данного слова: с.-в.-р. держа́ва, ласкат. - о супруге (Барсов, Причит.) [8].

Основные результаты анализа словарных статей в аспекте мотивирующих признаков приводятся в табл. 1.

Т а б ли ц а 1

Мотивирующие признаки макроконцепта держава по данным этимологических словарей

\begin{tabular}{|c|c|c|c|c|c|c|c|c|c|c|c|c|}
\hline $\begin{array}{l}\text { № } \\
\Pi / \Pi\end{array}$ & $\begin{array}{c}\text { Мотивирующие признаки } \\
\text { макроконцепта держава }\end{array}$ & 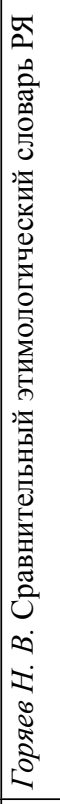 & 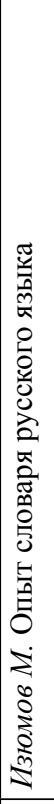 & 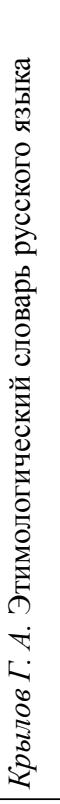 & 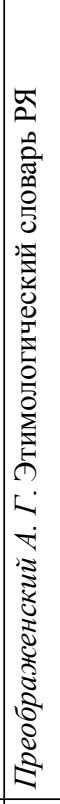 & 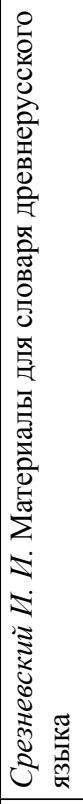 & 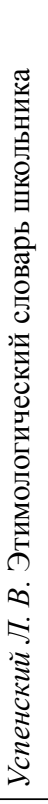 & 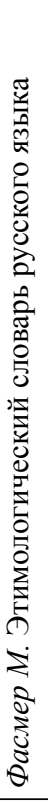 & 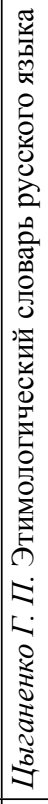 & 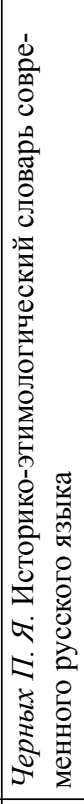 & 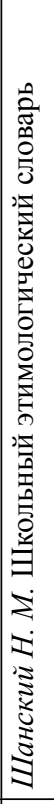 & 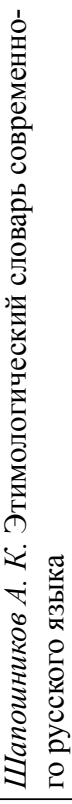 \\
\hline 1 & 'власть' & - & - & - & - & + & + & - & + & + & - & + \\
\hline 2 & 'владение' & + & - & - & + & + & - & - & - & - & - & - \\
\hline 3 & ‘владеть/править' & - & - & - & - & - & - & - & + & - & - & - \\
\hline 4 & 'владычество' & - & - & - & - & - & + & - & - & - & - & - \\
\hline 5 & ‘государство’ & - & - & - & - & + & - & - & - & - & - & + \\
\hline 6 & ‘дергать’ & - & + & - & - & - & - & - & - & - & - & - \\
\hline 7 & 'держать (в руках)’ & + & + & + & + & - & + & + & + & - & - & + \\
\hline 8 & ‘могущество’ & + & - & - & - & - & - & - & + & + & + & - \\
\hline 9 & 'область (которую властитель держит под своей властью)' & - & - & - & - & - & + & - & - & + & - & - \\
\hline 10 & 'основа' & - & - & - & - & - & - & - & - & + & - & + \\
\hline 11 & ‘основание' & - & - & - & - & + & - & - & - & + & - & + \\
\hline 12 & ‘подвластный народ’ & - & - & - & - & + & - & - & - & - & - & - \\
\hline 13 & ‘поддержка’ & - & - & - & - & + & - & - & - & - & - & - \\
\hline 14 & ‘символ власти: золотой шар с короной и крестом’ & - & - & + & - & - & + & - & - & - & - & - \\
\hline 15 & 'сила/крепость' & - & - & - & - & + & - & - & + & + & + & + \\
\hline 16 & '(самостоятельная) страна' & - & - & - & - & - & + & + & + & + & - & - \\
\hline 17 & 'супруга' & - & - & - & - & - & - & + & - & - & - & - \\
\hline 18 & 'твёрдый/крепкий’ & - & + & - & - & - & - & - & - & - & - & - \\
\hline 19 & ‘править/управление’ & + & - & - & - & + & - & - & + & + & - & - \\
\hline
\end{tabular}


В результате анализа этимологии слова держава основного репрезентанта изучаемого макроконцепта, следует заметить, что выделенные 19 мотивирующих признаков макроконцепта держава не указаны в полном объеме ни в одном из этимологических словарей. В словарях отмечается от двух (словарь А. Г. Преображенского) до восьми мотивирующих признаков (словари И. И. Срезневского [9], Г. П. Цыганенко и П. Я. Черных) макромакроконцепта держава. Ни один из словарей не дает полного списка мотивирующих признаков, указывая в среднем от трех [10] до шести [11].

Мотивирующие признаки макромакроконцепта держава можно представить в виде семи блоков: 1) физическое свойство ('дергать', 'могущество', 'сила/крепость', 'твёрдый/крепкий’); 2) собственность ('владение'); 3) фундамент ('поддержка', 'основа', 'основание'); 4) территория ('область (которую властитель держит под своей властью)'; 'государство', ‘(самостоятельная) страна'); 5) ценный предмет ('держать (в руках)', 'символ власти: золотой шар с короной и крестом’); 6) правление ('владеть/править', ‘владычество', ‘власть', ‘править/управление', ‘подвластный народ’); 7) род/семья ('супруга').

\section{2. Развитие понятийных признаков макро- кониепта держава}

Рассмотрим промежуточный этап дальнейшего развития макроконцепта держава в русской лингвокультуре. Обратимся к словарям старославянского, церковнославянского языков, а также словарям русского языка XVIII-XIX вв. На этом этапе было взято семь словарей [12-18].

Большая часть словарей этого типа указывают на наличие таких понятийных признаков макроконцепта держава, как 'владычество', 'могущество', 'регалия / символ власти: золотой шар с короной и крестом / царское яблоко', '(самостоятельная) страна/государство', '(верховная) власть'. Все словари приводят признак 'сила/крепость'.

Два словаря - В. И. Даля и Словарь церковнославянского и русского языка - приводят значения слова держава, связанные с ковкой и обработкой железа при производстве железных изделий [12; 18]. «Словарь русского языка» показывает, что признак 'расход/ потребление/издержка’ в XVIII в. относится уже не к макроконцепту держава, а характеризует устаревшую лексему держа, отмечая последнюю пометой обл. и давая вариант держ [17, с. 103].

Держава в «Словаре церковнославянского и русского языка» определяется в последних трех значениях: 4) Горн. Железная полоса, приваренная к какой-либо части якоря или к крице для удобнейшего управления ими при ковании. б) Горн. Железный стержень, употребляемый для садки серебряных слитков или бликов в сереброплавиленный горн. 6) Горн. Железный прут, на одном конце имеющий вид вил, а на другом загнутый в кольцо, для вкладывания рукоятки, и употребляемый при сварке железа» [18, стлб. 664]. В словаре В. И. Даля эти значения перечисляются и приводятся в качестве одного ЛСВ.

Результаты анализа словарных статей приведены в табл. 2.

В процессе анализа словарей русского языка промежуточного периода XVIII-XIX вв. было отмечено 23 понятийных признака макроконцепта держава. Самое большое количество понятийных признаков указано в словаре В. И. Даля (16).

Промежуточный период развития русского языка показал наличие 23 понятийных признака. Понятийные признаки макроконцепта держава промежуточного периода можно представить в виде семи блоков: 1) физическое свойство ('могущество', 'сила/крепость' - они же мотивирующие; 'утверждение'); 2) собственность ('(самостоятельное/независимое) владение' - мотивирующий признак 'владение'); 3) обработка и применение железа - ковка и строительство ('железная полоса (привариваемая временно к выковываемой крупной вещи для удержания и управлению ею на наковальне) / железный прут вилами, употребляемый для сварки железа / подобный стержень для садки серебряных бликов (слитков) в плавильный горн'; 'прочность / твердая связь / надежность в скрепе'; ‘укрепление'); 4) территория ('государство', 'область (которую властитель держит под своей властью)'; ‘(самостоятельная) страна' - они же мотивирующие; 'земля'); 5) ценный предмет ('держать (в руках)' - он же мотивирующий; 'регалия / символ власти: золотой шар с короной и крестом / царское яблоко' - мотивирующий признак 'символ власти: золотой шар с короной и крестом'); 6) правление народом ('(верховная) власть' - мотивирующий признак 'власть'; 'владычество', 'править/управление' - они же мотивирующие; 'народ', 'обращение (к владыке/государю)', 'правительство’); 7) род/семья ('владеть/править' - он же мотивирующий; 'содержание/уход/забота’ - мотивирующий признак 'супруга'); 8) опора ('за что можно держаться/ухватиться: поручни, ручка, рукоять, скоба, хватка'); 9) ресурсы ('расход/потребление/издержка').

Часть мотивирующих признаков сохранилась, другая часть трансформировалась. Мотивирующие признаки макроконцепта держава 'основа' и 'основание' в словарях данного периода не зафиксированы. Однако их место заняли понятийные признаки, связанные с промышленностью и производством: см. блок «Обработка и применение железа - ковка и строительство» ('железная полоса (привариваемая временно к выковываемой крупной вещи для удер- 
Т а б л и ц а 2

Понятийные признаки макроконцепта держава по данным толковых словарей русского языка ХVIII-XIX вв. и словарей старославянского и иерковнославянского языков

\begin{tabular}{|c|c|c|c|c|c|c|c|c|}
\hline $\begin{array}{l}\text { № } \\
\Pi / \Pi\end{array}$ & Понятийные признаки макроконцепта держава & 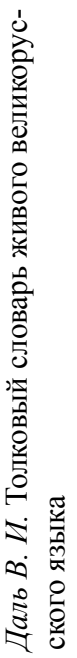 & 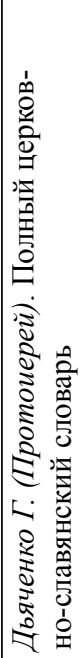 & 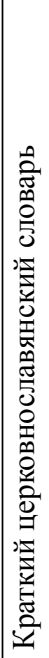 & 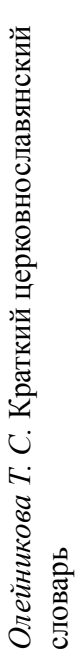 & 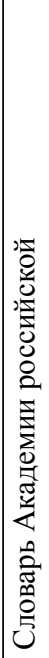 & 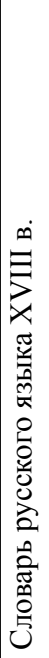 & 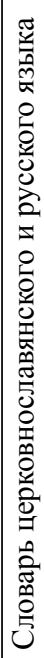 \\
\hline 1 & ‘(верховная) власть’ & - & + & + & + & + & + & - \\
\hline 2 & '(самостоятельное/независимое) владение' & + & - & - & - & - & + & + \\
\hline 3 & 'владеть/править' & - & - & - & - & - & - & - \\
\hline 4 & ‘владычество’ & + & - & + & + & + & + & + \\
\hline 5 & ‘государство’ & - & - & + & - & - & - & - \\
\hline 6 & 'держать (в руках)’ & - & - & - & - & - & - & - \\
\hline 7 & $\begin{array}{l}\text { ‘железная полоса (привариваемая временно к выковываемой крупной вещи для } \\
\text { удержания и управлению ею на наковальне) / железный прут вилами, употре- } \\
\text { бляемый для сварки железа / подобный стержень для садки серебряных бликов } \\
\text { (слитков) в плавильный горн' }\end{array}$ & + & - & - & - & - & - & + \\
\hline 8 & ‘за что можно держаться/ухватиться: поручни, ручка, рукоять, скоба, хватка' & + & - & - & - & - & - & - \\
\hline 9 & ‘земля’ & + & - & - & - & + & - & - \\
\hline 10 & ‘могущество’ & + & - & + & + & + & + & + \\
\hline 11 & 'народ’ & + & - & - & - & - & - & - \\
\hline 12 & ‘область (которую властитель держит под своей властью)’ & - & - & - & - & - & + & - \\
\hline 13 & ‘обращение (к владыке/государю)’ & - & - & - & - & - & + & - \\
\hline 14 & ‘правительство' & + & - & - & - & - & - & - \\
\hline 15 & ‘прочность / твердая связь / надежность в скрепе’ & + & - & - & - & - & - & - \\
\hline 16 & ‘расход/потребление/издержка' & + & - & - & - & - & - & - \\
\hline 17 & ‘регалия / символ власти: золотой шар с короной и крестом / царское яблоко’ & + & - & - & - & + & + & + \\
\hline 18 & ‘сила/крепость’ & + & + & + & + & + & + & + \\
\hline 19 & ‘содержание/уход/забота’ & + & - & - & - & - & - & - \\
\hline 20 & '(самостоятельная) страна' & + & - & - & + & + & + & + \\
\hline 21 & ‘править/управление’ & - & - & - & - & + & - & - \\
\hline 22 & ‘укрепление' & - & + & - & - & - & - & - \\
\hline 23 & 'утверждение' & - & + & - & - & - & - & - \\
\hline
\end{tabular}


жания и управления ею на наковальне) / железный прут вилами, употребляемый для сварки железа / подобный стержень для садки серебряных бликов (слитков) в плавильный горн'; ‘прочность / твердая связь / надежность в скрепе'; 'укрепление').

\section{3. Понятийные признаки макрокониепта держава в современной русской языковой картине мира}

Следующий этап изучения структуры - выявление понятийных признаков макроконцепта держава путем анализа соответствующих словарных статей в толковых словарях русского языка современного периода. Было взято 11 толковых и энциклопедических словарей современного русского языка.

В современный период заметно вытеснение первых значений. У слова держава появляется помета в первом значении «1. Полит. Независимое государство, обладающее силой и влиянием в международных делах» [19, с. 718]. Это значение в словаре С. И. Ожегова и Н. Ю. Шведовой трансформируется в «Большая и мощная страна»; оно уточняется: «(наиболее крупные государства, которые обладают большим экономическим и военным потенциалом и играют главную роль в мировой политике и международных отношениях)» [20].

У слова держава сохраняются значения «владычество, могущество, власть» и «Истор. золотой шар с крестом или короной, эмблема императорской власти, владычества над землей; царское яблоко» (где 'регалия' заменена на 'эмблему') [19, с. 718]. «Большой современный толковый словарь русского языка» дополняет «в Российском государстве до 1917 г.» [21]. У С. И. Ожегова и Н. Ю. Шведовой слово регалия в определении этого значения сохраняется [20]. Т. Ф. Ефремова использует прежнее определение «Золотой шар с крестом или короной на верхней части как символ власти монарха» [22]. При этом в Малом академическом словаре первое значение уточняется пометами «высок. устар. Верховная власть; владычество», а второе имеет помету: «ист. Золотой шар с крестом наверху, служивший эмблемой власти монарха» [23, с. 389].

Значение «В просторечии и обл. Способность держаться в известном положении; прочность» [19, c. 718] указывает на сохранение понятийного признака 'прочность / твердая связь / надежность в скрепе' (Для державы железные полосы в стене заложены), однако примеры к этому значению в словаре даются из словаря В. И. Даля.

В современный период происходит трансформация некоторых значений слова держава. Так, значение «Приспособление для держания чего-нибудь, например металла при обработке (сnец.)» [24], которое находим у Д. Н. Ушакова, в предыдущий период у В. И. Даля описывается более подробно: «железная полоса (привариваемая временно к выковываемой крупной вещи для удержания и управлению ею на наковальне) / железный прут вилами, употребляемый для сварки железа / подобный стержень для садки серебряных бликов (слитков) в плавильный горн» [12].

У слова держава в новый период появляются новые значения: 1) «государство, имеющее большие достижения в какой-либо области (экономической, военной, спортивной и т. п.)» [21]; 2) «поддержка, устой» $[19$, с. 718]. Приведем полученные данные этих и других толковых словарей [25-29] в табл. 3.

Анализ толковых словарей показал следующие результаты. В толковых словарях современного русского языка всего было выявлено 15 понятийных признаков у макроконцепта держава.

У макроконцепта держава исчезли следующие понятийные признаки, бывшие у него в предшествующие периоды: 'владеть/править', 'держать (в руках)', 'народ', 'область (которую властитель держит под своей властью)', 'обращение (к владыке/государю)', 'основа', 'основание', 'правительство', 'расход/ потребление/издержка', 'содержание/уход/забота', 'упруга', 'править/управление', 'укрепление', 'утверждение', 'уход'.

Часть мотивирующих признаков макроконцепта держава сохранила свою актуальность до нового времени. Среди таких признаков: 'владычество', ‘могущество'.

Группа понятийных признаков макроконцепта держава расширилась за счет появления новых признаков: '(большие) достижения (экономические, военные, спортивные и др.)', 'влияние (в мировой политике и международных делах)', 'потенциал (экономический/политический)'.

Некоторые понятийные признаки предшествующих периодов трансформировались. Понятийный признак '(самостоятельная) политика' восходит к мотивирующему '(самостоятельное/независимое) владение'). Понятийный признак 'земля' в современное время приобретает иной вид: 'территория (государства)'.

В диахронии русского языка происходит первоначальное расширение, а затем сужение понятийных признаков. Так, мотивирующий признак 'сила/крепость' сначала переходит в понятийный признак 'сила/крепость', позже сужаясь до понятийного признака 'сила'. Мотивирующий признак 'символ власти монарха: золотой шар с короной и крестом' первоначально расширяется до понятийного признака предшествующего периода 'регалия / символ власти монарха: золотой шар с короной и крестом / царское яблоко', позже он становится вариативным, при этом утрачивает некоторые детали: 'эмблема/ 
Т а б ли и ц 3

Понятийные признаки макроконцепта держава в толковых и энциклопедических словарях русского языка $X X-X X I$ вв.

\begin{tabular}{|c|c|c|c|c|c|c|c|c|c|c|c|c|}
\hline $\begin{array}{l}\text { № } \\
\Pi / \Pi\end{array}$ & $\begin{array}{c}\text { Понятийные признаки } \\
\text { макроконцепта держсава }\end{array}$ & 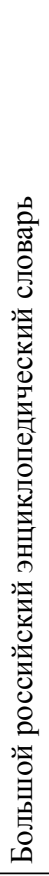 & 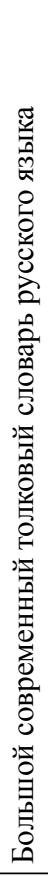 & 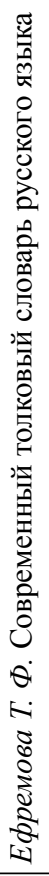 & 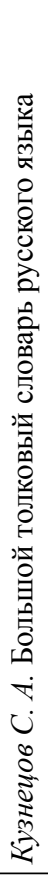 & 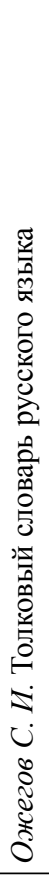 & 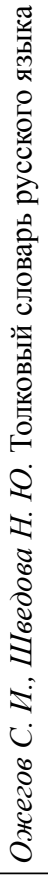 & 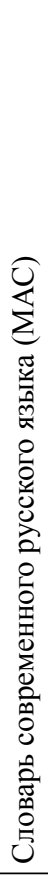 & 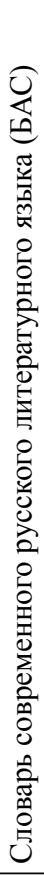 & 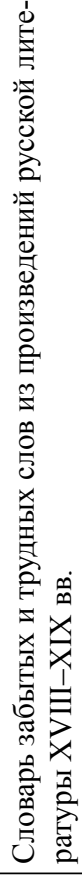 & 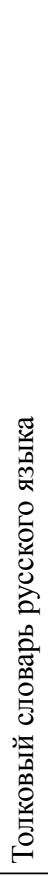 & 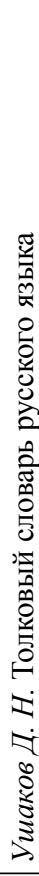 \\
\hline 1 & ‘(верховная/государственная) власть’ (мотивир. ‘власть’) & - & + & + & + & - & - & + & + & + & - & + \\
\hline 2 & $\begin{array}{l}\text { '(большие) достижения (экономические, военные, спортивные } \\
\text { и др.)' }\end{array}$ & - & + & - & - & + & - & - & - & - & + & - \\
\hline 3 & ‘владычество’ & - & - & - & + & - & - & + & + & + & - & + \\
\hline 4 & ‘влияние (в мировой политике и международных делах)’ & - & - & - & - & + & + & - & + & - & + & + \\
\hline 5 & $\begin{array}{l}\text { ‘приспособление для держания чего-нибудь, например металла } \\
\text { при обработке (спец.)’ (в пред. период ‘железная полоса (прива- } \\
\text { риваемая временно к выковываемой крупной вещи для удержания } \\
\text { и управления ею на наковальне) / железный прут вилами, упо- } \\
\text { требляемый для сварки железа / подобный стержень для садки } \\
\text { серебряных бликов (слитков) в плавильный горн’ }\end{array}$ & - & - & - & - & - & - & - & - & - & - & + \\
\hline 6 & $\begin{array}{l}\text { 'за что можно держаться/ухватиться (поручни, ручка, рукоять, } \\
\text { скоба, хватка)' }\end{array}$ & - & - & - & - & - & - & - & + & - & - & - \\
\hline 7 & ‘территория (государства) (понят. признак пред. периода ‘земля’)' & - & - & + & - & - & - & - & - & - & - & - \\
\hline 8 & ‘могущество’ & - & - & - & - & - & - & - & + & + & - & - \\
\hline 9 & ‘поддержка/устой’ & - & - & - & - & - & - & - & + & + & - & - \\
\hline 10 & $\begin{array}{l}\text { ‘(самостоятельная) политика' (мотивир. '(самостоятельное/незави- } \\
\text { симое) владение’) }\end{array}$ & - & - & + & + & - & - & + & - & + & + & - \\
\hline 11 & ‘потенциал (экономический/политический)’ & - & - & - & - & - & + & - & - & - & - & - \\
\hline 12 & ‘прочность / твердая связь / надежность в скрепе' & - & - & - & - & - & - & - & + & - & - & - \\
\hline 13 & $\begin{array}{l}\text { 'эмблема/регалия/символ власти монарха: золотой шар с короной } \\
\text { или крестом' }\end{array}$ & + & + & + & + & + & + & + & + & + & + & + \\
\hline 14 & 'сила’ (мотивир. 'сила/крепость’) & - & + & - & - & & - & - & + & - & - & - \\
\hline 15 & $\begin{array}{l}\text { ((большая/мощная страна/независимое/крупное государство’) } \\
\text { (мотивир. ‘(самостоятельная) страна/государство’) }\end{array}$ & + & + & + & + & + & + & + & + & + & + & + \\
\hline
\end{tabular}


регалия/символ власти монарха: золотой шар с короной или крестом'.

История развития русского языка показывает расширение мотивирующих признаков. Мотивирующий признак 'власть' приобрел иной вид: ‘(верховная/ государственная) власть'.

Возможен обратный процесс - сужение. Современный понятийный признак ‘прочность' ранее был синкретичным 'прочность / твердая связь / надежность в скрепе'. Понятийный признак, упоминаемый в словаре В. И. Даля, 'железная полоса (привариваемая временно к выковываемой крупной вещи для удержания и управления ею на наковальне) / железный прут вилами, употребляемый для сварки железа / подобный стержень для садки серебряных бликов (слитков) в плавильный горн' предстает ныне в обобщенном виде: 'приспособление для держания чего-нибудь, например металла при обработке (спец.)'. Понятийный признак 'за что можно держаться/ухватиться (поручни, ручка, рукоять, скоба, хватка)’ упоминается только в одном словаре (БАС), где сокращается до 'то, за что можно держаться/ухватиться (ручка, скоба)'. Понятийный признак 'поддержка/ устой' сокращается до 'поддержка'

\section{Заключение}

В целом, развитие структуры макроконцепта держава происходит волнообразно. Мотивирующих признаков у данного макроконцепта 19, в период с $\mathrm{X}$ по XIX в. у него появляется 23 понятийных признака. В современной русской языковой картине мира понятийных признаков осталось 15 . В таком случае речь идет об угасающем макроконцепте, у которого понятийные признаки меньше, чем мотивирующие.

Понятийные признаки современного макроконцепта держава можно обобщить в виде 9 блоков: 1) правление народом ('(верховная/государственная) власть' (мотивир. 'власть'), 'владычество'); 2) взаимоотношения между странами ('влияние (в мировой политике и международных делах)', '(самостоятельная) политика' - мотивир. '(самостоятельное/независимое) владение'); 3) земля с границами ('(большая /мощная страна / независимое/крупное государство') (мотивир. '(самостоятельная) страна/государство'), 'территория (государства) (понят. признак пред. периода 'земля')'); 4) физические способности ('сила' (мотивир. 'сила/крепость'), 'могущество'); 5) возможности и ресурсы ('(большие) достижения (экономические, военные, спортивные и др.)', 'потенциал (экономический/политический)'); 6) опора ('поддержка', 'за что можно держаться/ухватиться (ручка, скоба)'); 7) предмет ('приспособление для держания чего-нибудь, например металла при обработке (спец.)' (в пред. период 'железная полоса (привариваемая временно к выковываемой крупной вещи для удержания и управления ею на наковальне) / железный прут вилами, употребляемый для сварки железа / подобный стержень для садки серебряных бликов (слитков) в плавильный горн'); 8) знак ('эмблема/ регалия/символ власти монарха: золотой шар с короной или крестом'); 9) физическое свойство ('прочность / твердая связь / надежность в скрепе').

\section{ЛИТЕРАТУРА}

1. Успенский Л. В. Этимологический словарь школьника. URL: https://lexicography.online/etymology/uspensky/д/держава

2. Горяев Н. В. Сравнительный этимологический словарь русского языка. Тифлис : Тип. Канцелярии главнонач. гражд. ч. на Кавказе, 1896. С. 89.

3. Цыганенко Г. П. Этимологический словарь русского языка : более 5000 слов. 2-е изд., перераб. и доп. Киев : Рад. шк., 1989. С. 106.

4. Преображенский А. Г. Этимологический словарь русского языка. М. : Типография Г. Лисснера и Д. Совко, 1910-1914. T. 1. C. 181.

5. Крылов Г. А. Этимологический словарь русского языка. СПб. : Полиграфуслуги, 2005. С. 111.

6. Шанский Н. М. Школьный этимологический словарь. 2-е изд. М. : Дрофа, 2000. 399 с.

7. Черных П. Я. Историко-этимологический словарь современного русского языка: в 2 т. 3-е изд., стереотип. М. : Русский язык, 1999. Т. 1. С. 243.

8. Фасмер М. Этимологический словарь русского языка : в 4 т. / пер. с нем. и доп. О. Н. Трубачева. 2-е изд., стер. Т. 1: (А-Д). М. : Прогресс; 1986. С. 327, 344. URL: https://lexicography.online/etymology/vasmer/д/держава

9. Срезневский И. И. Материалы для словаря древнерусского языка по письменным памятникам : в 3 т. СПб. : Типография Императорской Академии наук, 1893. T. I. A-K. C. 773-774.

10. Изюмов М. Опыт словаря русского языка сравнительно с языками индо-европейскими : в 4 отд. СПб. : Издание книгопродавца Шигина, 1880. С. 53-54.

11. Шапошников А. К. Этимологический словарь современного русского языка: в 2 т. 2-е изд., стер. М. : ФЛИНТА, 2016. Т. I (А-Н). С. 2.

12. Даль В. И. Толковый словарь живого великорусского языка : в 4 т. СПб., 1863-1866. Репр. изд. СПб. : Диамант, 1996. Т. 1: А-3. С. 443.

13. Краткий церковнославянский словарь. URL: https:/gufo.me/dict/church slavonic/держава

14. Олейникова Т. С. Краткий словарь малопонятных слов и выражений церковнославянского языка. URL: http://bible.ucoz.com/load/biblejskie_ehnciklopedii_i_slovari/skachat_biblejskij_slovar/olejnikova_t_s_kratkij_slovar maloponjatnykh slov i vyrazhenij cerkovnoslavjanskogo_jazyka_2005_doc_rus/11-1-0-2251

15. Полный церковнославянский словарь (с внесением в него важнейших древнерусских слов и выражений) / сост. свящ. Григорий Дьяченко. 1900. С. 141. 
16. Словарь Академии российской. СПб. : Академия наук, 1790. Ч. ІІ. От Г до З. Стбл. 610.

17. Словарь русского языка XVIII века. Л. : Наука, Ленинградское отделение, 1991. Вып. 6. Грызться Древный. С. 103.

18. Словарь церковнославянского и русского языка / сост. Вторым отделением императорской Академии наук. СПб. : Типография Императорской Академии наук, 1847. T. 1. С. 663-664.

19. Словарь современного русского литературного языка (БАС) : в 17 т. М. ; Л. : Изд-во АН СССР, 1954. T. III. Г. С. 718.

20. Ожегов С. И., Шведова Н. Ю. Толковый словарь русского языка. 1949-1992. URL: https://dic.academic.ru/ dic.nsf/ogegova/46998

21. Большой современный толковый словарь русского языка. 2012. URL: https://slovar.cc/rus/tolk/23603. html

22. Ефремова Т. Ф. Современный толковый словарь русского языка. 2005. URL: https://slovar.cc/rus/ efremova/153955.html

23. Словарь современного русского языка (МАС) : в 4 т. / РАН, Ин-т лингвистич. исследований ; под ред. А. П. Евгеньевой. 3-е изд., стер. М. : Русский язык, 1985. T. I. А-Й. С. 389.

24. Ушаков Д. Н. Толковый словарь русского языка. 1935-1940. URL: https://dic.academic.ru/dic.nsf/ushakov/787430

25. Большой российский энциклопедический словарь. 2000. URL: https://dic.academic.ru/dic.nsf/enc3p/116698

26. Кузнеияов C. А. Большой толковый словарь русского языка. СПб. : Норинт, 2000. С. 252.

27. Ожегов С. И. Толковый словарь русского языка. URL: http:/ччто-означает.pф/держава

28. Словарь забытых и трудных слов из произведений русской литературы XVIII-XIX веков / сост. Л. А. Глинкина. 1998. URL: https://difficult_words_ru. academic.ru/625/держава

29. Толковый словарь русского языка. URL: https:// www.vedu.ru/expdic/6809/

\section{REFERENCES}

1. Uspensky L. V. Etimologicheskij slovar' shkol'nika [Etymological dictionary of the schoolchild]. Available at: https://lexicography.online/etymology/uspensky/d/power

2. Goryaev N. V. Sravnitel'nyj ehtimologicheskij slovar' russkogo yazyka [Comparative etymological dictionary of the Russian language]. Tiflis: Typeography Office of the chief citizen h. in the Caucasus, 1896. P. 89.

3. Tsyganenko G. P. Etimologicheskij slovar' russkogo yazyka [Etymological dictionary of the Russian language]. Kiev, 1989. P. 106.

4. Preobrazhensky A. G. Etimologicheskij slovar' russkogo yazyka [Etymological dictionary of the Russian language]. Moscow: Printing house of G. Lissner and D. Sovko, 1910-1914. Vol. 1. P. 181.
5. Krylov G. A. Etimologicheskij slovar' russkogo ya$z y k a$ [Etymological dictionary of the Russian language]. Saint Petersburg: LLC Polygraphuslugi, 2005. P. 111.

6. Shansky N. M. Shkol'nyj ehtimologicheskij slovar' [School etymological dictionary]. Moscow: Bustard, 2000. $399 \mathrm{p}$.

7. Chernykh P. Ya. Istoriko-ehtimologicheskij slovar' sovremennogo russkogo yazyka: $v 2 t$. [Historical and etymological dictionary of the modern Russian language: in 2 volumes]. Moscow: Russian language, 1999. Vol. 1. P. 243.

8. Fasmer M. Etimologicheskij slovar' russkogo yazyka: $v 4 t$. [Etymological dictionary of the Russian language: in 4 volumes]; ed. by O. N. Trubachev. Iss. 1. Moscow: Progress, 1986. Pp. 327, 344. Available at: https://lexicography. online/etymology/vasmer/д/power

9. Sreznevsky I. I. Materialy dlya slovarya drevnerusskogo yazyka po pis'mennym pamyatnikam: $v 3 t$. [Materials for the dictionary of the Old Russian language on written monuments: in 3 volumes]. Saint Petersburg, 1893. Iss. I. Pp. 773-774.

10. Izyumov M. Opyt slovarya russkogo yazyka sravnitel'no s yazykami indo-evropejskimi [Experience of the dictionary of the Russian language in comparison with the Indo-European languages]. Saint Petersburg: Edition of the bookseller Shigin, 1880. Pp. 53-54.

11. Shaposhnikov A. K. Etimologicheskij slovar' sovremennogo russkogo yazyka: $v 2 t$. [Etymological Dictionary of the Modern Russian Language: in 2 volumes]. Moscow: FLINTA, 2016. Vol. I (A-N). P. 2.

12. Dal' V. I. Tolkovyj slovar' zhivogo velikorusskogo yazyka: $v 4 t$. [Explanatory Dictionary of the Living Great Russian Language: in 4 volumes]. Saint Petersburg, 18631866. Repr. ed. Saint Petersburg: Diamant, 1996. Vol. 1. P. 443.

13. Kratkij tserkovnoslavyanskij slovar' [A Brief Church Slavonic Dictionary]. Available at: https:/gufo.me/dict/ church_slavonic/power

14. Oleinikova T. S. Kratkij slovar' maloponyatnykh slov $i$ vyrazhenij tserkovnoslavyanskogo yazyka [A short dictionary of obscure words and expressions of the Church Slavonic language]. 2005. Available at: http:// bible.ucoz.com/load/biblejskie_ehnciklopedii_i_slovari/ skachat_biblejskij_slovar/olejnikova_t_s_kratkij_slovar_ maloponjatnykh_slov_i_vyrazhenij_cerkovnyanskjansk 2005_jazhenij_cerkovnoslav_25oc1_doc1

15. Polnyj tserkovnoslavyanskij slovar' (s vneseniem v nego vazhnejshikh drevnerusskikh slov i vyrazhenij) [A complete Church Slavonic dictionary (with the introduction of the most important Old Russian words and expressions)]; ed. Grigory Dyachenko. 1900. P. 141.

16. Slovar' Akademii rossijskoj [Dictionary of the Russian Academy]. Saint Petersburg: Academy of Sciences, 1790. Part II. St. 610.

17. Slovar' russkogo yazyka XVIII veka [Dictionary of the Russian language of the 18th century]. Leningrad: Science, Leningrad branch, 1991. Iss. 6. P. 103. 
18. Slovar' tserkovnoslavyanskogo i russkogo yazyka [Dictionary of Church Slavonic and Russian language]. Saint Petersburg: Printing house of the Imperial Academy of Sciences, 1847. Vol. 1. Pp. 663-664.

19. Slovar' sovremennogo russkogo literaturnogo yazyka: v 17 t. [Dictionary of the modern Russian literary language: in 17 volumes]. Moscow ; Leningrad: Publishing house of the Academy of Sciences of the USSR, 1954. Vol. III. P. 718.

20. Ozhegov S. I., Shvedova N. Yu. Tolkovyj slovar russkogo yazyka [Explanatory dictionary of the Russian language]. 1949-1992. Available at: https://dic.academic. ru/dic.nsf/ogegova/46998

21. Bol'shoj sovremennyj tolkovyj slovar' russkogo yazyka [A large modern explanatory dictionary of the Russian language]. 2012. Available at: https://slovar.cc/rus/ tolk/23603.html

22. Efremova T. F. Sovremennyj tolkovyj slovar' russkogo yazyka [Modern explanatory dictionary of the Russian language]. 2005. Available at: https://slovar.cc/rus/efremova/153955.html

23. Slovar' sovremennogo russkogo yazyka: v 4-kh t. [Dictionary of the modern Russian language: in 4 volumes];

\author{
Институт иностранных языков \\ Демидова Е. Е., преподаватель \\ E-mail: Demidova_Eu@mail.ru
}

Поступила в редакичю 12 июля 2021 г.

Принята к публикаџии 15 октября 2021 г.

\section{Для циитирования:}

Демидова Е. Е. Развитие структуры макроконцепта держава от мотивирующих признаков до понятийных // Вестник Воронежского государственного университета. Серия: Лингвистика и межкультурная коммуникация. 2021. № 4. C. 28-37. DOI: https://doi.org/10.17308/ lic. $2021.4 / 3808$ ed. A. P. Evgenieva. Moscow: Russian language, 1985. Vol. I. P. 389.

24. Ushakov D. N. Tolkovyj slovar' russkogo yazyka [Explanatory dictionary of the Russian language]. 19351940. Available at: https://dic.academic.ru/dic.nsf/ushakov/787430

25. Bol'shoj rossijskij ehntsiklopedicheskij slovar' [The Big Russian Encyclopedic Dictionary]. 2000. Available at: https://dic.academic.ru/dic.nsf/enc3p/116698

26. Kuznetsov S. A. Bol'shoj tolkovyj slovar' russkogo yazyka [Great Dictionary of Russian language]. Saint Petersburg: Norint, 2000. P. 252.

27. Ozhegov S. I. Tolkovyj slovar' russkogo yazyka [Explanatory dictionary of the Russian language]. Available at: http: //what-means.pф/power

28. Slovar' zabytykh i trudnykh slov iz proizvedenij russkoj literatury XVIII-XIX vekov [Dictionary of forgotten and difficult words from the works of Russian literature of the $18^{\text {th }}-19$ th centuries]; comp. L. A. Glinkina. 1998 . Available at: https:/difficult_words_ru.academic.ru/625/ power

29. Tolkovyj slovar' russkogo yazyka [Explanatory dictionary of the Russian language]. Available at: https:// www.vedu.ru/expdic/6809/

\section{Institute of Foreign Languages \\ Demidova E. E., Lecturer \\ E-mail: Demidova_Eu@mail.ru}

Received: 12 July 2021

Accepted: 15 October 2021

\section{For citation:}

Demidova E. E. The development of the structure of the держава (power) macroconcept from motivating signs to conceptual ones. Proceedings of Voronezh State University. Series: Linguistics and Intercultural Communication. 2021. No. 4. Pp. 28-37. DOI: https://doi.org/10.17308/lic.2021.4 13808 